\title{
A CONSIDERATION OF KETAMINE DREAMS
}

\author{
Paul HejJa and Samuel Galloon
}

A MULTIrUDE of investigators have reported on the incidence of emergence reactions and dreams following ketamine $\mathrm{HCl}$ anaesthesia, drawing attention especially to the visual nature of these disturbances. Stolp et al. in $1968^{1}$ concluded that the waking stage after anaesthesia with ketamine $\mathrm{HCl}$ does not involve hallucinations in the strict sense, but rather involves perception of incoming stimuli to the brain, and that these fade as the drug effect is dissipated, and are never recorded after full consciousness has been regained. In their paper, they draw attention to maintaining sufficient depth of anaesthesia to avoid external stimuli from impinging on the patient's sensory modalities, and to covering the eyes in the recovery period.

Since virtually all the psychic manifestations of ketamine $\mathrm{HCl}$ have visual disturbances as their basis, a study was planned to assess the effects of masking the eyes, during the operation and in the post-operative period, to discover the point at which these "dreams" occur during the anaesthetic sequence, and to determine whether the incidence of visually-induced "dreams" could be modified.

\section{METHOD}

Because of the uniformity of the surgery involved in therapeutic dilatation and curettage ( $D \& C$ ), it was decided to utilize this group of patients for the study as we have done for previous investigations of this drug. ${ }^{2}$ One hundred and fifty patients undergoing therapeutic D \& $\mathrm{C}$ were included in the study. Only those graded in class one or two of the American Society of Anesthesiologists' classification of patients were included; patients with hypertension (160/90), cardiac disease, and those with significant psychiatric histories were excluded.

Premedication consisted of pantopon $0.28 \mathrm{mg} / \mathrm{kg}$ plus scopolamine $0.4 \mathrm{mg}$ given approximately 90 minutes before operation. Intravenous ketamine $\mathrm{HCl}$ was the sole agent for induction $(2.2 \mathrm{mg} / \mathrm{kg})$ and maintenance $(0.5 \mathrm{mg} / \mathrm{kg})$. Maintenance doses were administered only when a patient responded to surgical stimuli.

Each patient was allocated to one of three groups on a predetermined random basis designed to accommodate 150 cases. Group 1 patients acted as controls. Group 2 patients were fitted with goggles as soon as anaesthesia was induced, prior to any stimulation or manipulation. These were ski-goggles, with the plastic lenses replaced by black cardboard, so that the eyes were completely masked and no light could be seen even if the eyes were open. Upon transfer from the operating theatre at the end of the procedure, the goggles were removed. Group 3 patients were treated identically to Group 2 except that the goggles were left in place until the return of consciousness in the recovery room.

In the post-operative period, all patients were treated alike, and vital signs were monitored as usual, except that the disturbance of measuring and recording these

- Department of Anaesthesia, University of Toronto and Toronto General Hospital. 
signs was kept to a minimum consistent with patient safety. The recovery-room nurse was asked to complete a brief questionnaire listing specified observations, and the times at which they occurred. During the first twenty-four hours following anaesthesia, each patient was personally interviewed by the author who had not given the anaesthetic. Questions covered symptomatic complaints such as headache, dizziness and nausea, their "dream" experiences, and their willingness to have the same anaesthetic again. The objective data were submitted for statistical evaluation by an independent medical statistician.

\section{Results}

There was no relationship of height, weight, or body surface area (B.S.A.) to those who had dreams. When the dosage of ketamine was expressed in terms of height, weight, B.S.A., or even minutes of anaesthesia, no correlations became evident. This was not surprising considering the variable response of patients of similar physique to the induction and maintenance doses. None of the parameters under observation in the recovery room such as restlessness, aimless laughter, crying, or disorientation, could be related to more dreams in any of the three groups. The time spent in the recovery room in each group was not influenced by the total dose, nor the interval between the last dose and the return of consciousness. There was no statistical difference between the groups relating to nausea, vomiting, or both, even among those who dreamed in each group. However, the incidence of headache was considerably lower in Group 3, compared to Groups 1 and 2 (Table I), and dizziness also diminished somewhat, although the differences between the groups are not statistically significant. Auditory perception increased with the duration of covering the eyes (Table II, where $p$ is less than 0.05 for

TABLE I

Incidence of Headache and Dizziness, Related to the Three Groups of Patients

\begin{tabular}{lccccc}
\hline & \multicolumn{2}{c}{ All Patients } & & \multicolumn{2}{c}{ Patients Who Dreamed } \\
\cline { 2 - 3 } \cline { 5 - 6 } Group & Dizziness & Headache & & Dizziness & Headache \\
\hline $1(50)$ & $38(76 \%)$ & $16(32 \%)$ & & $15(83 \%)$ & $6(33 \%)$ \\
$2(50)$ & $34(68 \%)$ & $13(26 \%)$ & & $12(63 \%)$ & $7(37 \%)$ \\
$3(50)$ & $28(56 \%)$ & $7(14 \%)$ & & $9(60 \%)$ & $2(13 \%)$ \\
\hline \\
None of the changes between Groups 1,2 , and 3 are statistically \\
significant.
\end{tabular}

TABLE II

Sensory Modalities Experienced During Dreams

\begin{tabular}{lllll}
\hline & \multicolumn{4}{c}{ Modalities } \\
\cline { 2 - 5 } Group & Auditory & Olefactory & Visual & Tactile \\
\hline $1(50)$ & $2(4 \%)^{*}$ & $18(36 \%)$ & $18(36 \%)$ & $1(2 \%)$ \\
$2(50)$ & $3(6 \%)$ & $19(38 \%)$ & $19(38 \%)$ & $1(2 \%)$ \\
$3(50)$ & $7(14 \%)^{*}$ & $15(30 \%)$ & $13(26 \%)$ & - \\
\hline
\end{tabular}

*Statistically significant $\mathrm{p}<0.05$. 
TABLE III

Incidence of Pleasant and Unpleasant Dreams, Related to the THREE GROUPS

\begin{tabular}{lcccr}
\hline & \multicolumn{2}{c}{ Dreams } & & \\
\cline { 2 - 3 } Group & Pleasant & Unpleasant & Total & No Dreams \\
\hline $1(50)$ & $15(30 \%)$ & $3(6 \%)$ & $18(36 \%)$ & $32(64 \%)$ \\
$2(50)$ & $10(20 \%)$ & $9(18 \%)$ & $19(38 \%)$ & $31(62 \%)$ \\
$3(50)$ & $10(20 \%)$ & $5(10 \%)$ & $15(30 \%)$ & $35(70 \%)$ \\
Total $(150)$ & $35(23 \%)$ & $17(11 \%)$ & $52(35 \%)$ & $98(65 \%)$ \\
\hline
\end{tabular}

None of the changes between Groups 1,2, and 3 are statistically significant.

TABLE IV

INCIDENCE of DREams in Home-Dreamers

(See text for definition)

\begin{tabular}{|c|c|c|c|c|c|c|c|c|}
\hline \multirow[b]{3}{*}{ Home Dreamers } & \multicolumn{4}{|c|}{ Home Dreamers in this Study } & \multicolumn{4}{|c|}{ All Patients } \\
\hline & \multicolumn{2}{|c|}{ Total Dreams } & \multicolumn{2}{|c|}{ Unpleasant Dreams } & \multicolumn{2}{|c|}{ Total Dreams } & \multicolumn{2}{|c|}{ Unpleasant Dreams } \\
\hline & No. & $\%$ & No. & $\%$ & No. & $\%$ & No. & $\%$ \\
\hline $\begin{array}{l}\text { Group } 1 \\
21 \text { out of } 50\end{array}$ & 18 & 86 & 3 & 14.3 & 18 & 36 & 3 & 6 \\
\hline $\begin{array}{l}\text { Group } 2 \\
\quad 25 \text { out of } 50\end{array}$ & 18 & 72 & 9 & 36 & 19 & 38 & 9 & 18 \\
\hline $\begin{array}{l}\text { Group } 3 \\
22 \text { out of } 50\end{array}$ & 14 & 64 & 5 & 22.7 & 15 & 30 & 5 & 10 \\
\hline $\begin{array}{l}\text { Total } \\
\quad 68 \text { out of } 150\end{array}$ & 50 & 73.5 & 17 & 25 & 52 & 35 & 17 & 11 \\
\hline
\end{tabular}

None of the changes between Groups 1, 2, and 3 are statistically significant.

Group 3), but other sensory modalities were unaffected. Other authors (Galloon, Collier) did not reveal disturbances of other modalities. ${ }^{2.3}$

The overall incidence of dreams in this study was 35 per cent, of which 11.3 per cent were defined as unpleasant (Table III). The total number of dreams in Groups 2 and 3 was the same as in Group 1, but the total dreams and unpleasant dreams were lower in Group 3 than in Group 2, suggesting that the longer the goggles-are in place, the less is the incidence of dreams.

Table IV shows that $\mathbf{4 5}$ per cent of all patients were home-dreamers (defined as those patients who ordinarily dream at home) and the incidence of dreams among the home-dreamers was 75 per cent (50 out of 68 ). Only two of the 82 patients who were not home-dreamers had dreams during this anaesthetic (one in Group 2 and one in Group 3). The total incidence of dreams in the home-dreamers decreased from Group 1 down to Group 3, but the incidence of unpleasant dreams increased, more in Group 2 than in Group 3.

Approximately three-quarters of all patients said they would have the same anaesthetic in the future, whilst approximately one quarter said they didn't care. Only 3 patients out of 150 said they would not like to have the same anaesthetic; two of these three had unpleasant dreams. 


\section{Discussion}

The major disadvantage of ketamine is related to the post-operative period, and specifically to the high incidence of dreams or "hallucinations". It seems also that these dreams tend to be mostly of a visual nature. Many articles have dealt with the reduction of these dreams, mostly by changes in premedication. ${ }^{2,4}$ Only Stolp et $a{ }^{1}{ }^{1}$ briefly mentioned covering the eyes and allowing the patients to recover in a quiet dark room. In our study occluding the eyes did not reduce the overall incidence of dreams - 38 per cent of patients in Group 2 and 30 per cent in Group 3, dreamed; compared to 32 per cent in a previous study using the same premedication. ${ }^{2}$ We did not have the quiet dark room to go with covering the eyes, as we feel this is impossible to achieve in a large busy recovery room.

However, almost incidentally, it became evident that the incidence of dreaming is almost entirely in those patients who ordinarily dream at home (home-dreamers). The most interesting finding in this study was that only two out of eighty-two patients who were not home-dreamers actually dreamed during this anaesthetic. Neither of these two had an unpleasant dream. In addition, occlusion of the eyes until recovery (Group 3) in home-dreamers reduced the incidence of dreams, compared to the control group, and the unpleasant dreams in the group were also less than in Group 2 (Table IV). These reductions, although convincing, are not statistically significant.

It is readily appreciated from Table IV that individuals who do not ordinarily dream (non-home-dreamers) are not likely to have dreams. Occluding the eyes decreases the incidence of dreams in home-dreamers, and leaving the goggles on until recovery is better than leaving them on only in the operating room. From this, one might consider incorporating a question in the pre-operative assessment, concerning the usual frequency of dreaming at home, when ketamine is contemplated as the anaesthetic of choice. It may be advantageous to use occlusive goggles only in those patients identified as home-dreamers. The increase of unpleasant dreams could be overcome by using different pre-medications. ${ }^{2.4}$

The increase in audible disturbances in Group 2 (Table II) suggests that Stolp's suggestion of recovery in a quiet dark room may well help to reduce the dreams, although this may be physically difficult to do in many recovery rooms.

\section{SUMMARY}

This study was designed to see whether covering of the eyes during and after ketamine anaesthesia would reduce the incidence of dreams. One hundred and fifty patients, randomly divided into three groups, underwent therapeutic abortion with ketamine as the sole anaesthesia. One hundred patients had their eyes completely covered, 50 in the operating room only and 50 in the operating room and in the recovery room. The third 50 were controls, with their eyes uncovered. All patients were questioned post-operatively about dreams, nausea and vomiting, headache, dizziness and other experiences, and also how frequently they dreamed at home. Although covering the eyes in the recovery room only reduced the incidence of dreams marginally, it became obvious that the patients who dreamed after 
ketamine (in all 3 groups) were those who normally dreamed at home. There were 82 patients who were recorded as not being home-dreamers, and only two of these dreamed after ketamine. In contrast, of the 68 home-dreamers, 50 dreamed after ketamine, and 17 of these had unpleasant dreams. In the home-dreamers, covering the eyes reduced the incidence of dreams from 86 per cent in Group 1 to 72 per cent in Group 2 and 64 per cent in Group 3. It is suggested that goggles may be advantageous when dealing with home-dreamers, and a question about the patient's tendency to dream should be included in the preoperative questioning. Alterations in premedication and the use of a quiet dark room during recovery may even further reduce unpleasant dreams in this group.

\section{RÉSUMÉ}

Nous avons entrepris ce travail dans le but de trouver si le fait de couvrir les yeux durant et après une anesthésie à la Kétamine réduirait l'incidence des rêves. Nous avons formé au hasard trois groupes de cinquante patientes, chez des malades subissant sous Kétamine, comme seul agent d'anesthésie, un avortement thérapeutique.

Cent patients eurent les yeux complètement couverts; chez cinquante malades, les yeux furent couverts dans la salle d'opération seulement, et, chez les cinquante autres, dans la salle d'opération et la salle de réveil. Les cinquante autres malades, n'eurent pas les yeux couverts.

En post-opératoire, toutes les malades ont été questionnées pour déterminer l'incidence des rêves, des nausées, vomissements ou d'autres expériences; il leur fut également demandé combien fréquemment elles faisaient des rêves à la maison.

Le fait de couvrir les yeux ne réduit que peu l'incidence des rêves. Il s'est avéré clair, cependant, que les malades qui présentaient des rêves après la Kétamine (dans les trois groupes) étaient celles qui faisaient fréquemment des rêves chez elles.

Quatre vingt-deux patientes disaient ne pas rêver habituellement. Seulement deux d'entre elles rapportèrent des rêves après la Kétamine.

Par ailleurs chez 68 malades qui disent rêver fréquemment, 58 en rapportèrent après la Kétamine et chez 18 de ces patientes, les rêves étaient désagréables. Parmi celles qui disaient rêver fréquemment, on a retrouvé 86 pour cent de rêves après usage de Kétamine dans ce groupe contrôle (yeux non couvert); ceci se compare à une incidence de 72 pour cent, si les yeux couverts en salle d'opération et de 64 pour cent si les yeux sont laissés couverts jusqu’à éveil complet à la salle de réveil.

L'usage de lunettes à verre opaque éliminant toute lumière est donc suggéré chez les malades portés à rêver et l'on devrait demander aux malades s'ils rêvent fréquemment à domicile, lors de la visite pré-opératoire.

Des modifications à la prémédication et un éveil dans un local sombre et calme peuvent contribuer à diminuer davantage les rêves désagréables chez ces malades.

\section{ACKNOWLEDGMENTS}

We would like to thank Dr. R.A. Gordon, Chairman of the Department of Anaesthesia of the University of Toronto, for his constant help, advice and criticism 
during the study. Our thanks also to the nurses in the recovery room for their co-operation. Finally, our thanks to Parke, Davis and Company, Montreal, for their grant for the statistical analysis and the goggles, and to the Hospital for Sick Children Bio-Statistics Service for the processing of the results.

\section{REFERENCES}

1. Stolp, Von W., Langrehr, D., \& Solkol, K. Zur Anwendung von Ketamine in der Geburtshilflichen Anästhesie. Zeitschrift für Geburtshilfe und Gynäkologie 169: 198-213 (1968).

2. Galloon, S. Ketamine for dilatation \& curettage. Can. Anaesth. Soc. J. 18: 600-613 (1971).

3. Collier, B.B. Ketamine and the conscious mind. Anaesthesia 27: 120-134 (1972).

4. Abajian, J.C., Page, P., \& MohGan, M. Effects of droperidol and nitrazepam on emergence reactions following ketamine anaesthesia. Anaesth. Analg. 52: 385-389 (1973). 